Original article

\title{
Detection of bacterioplankton using PCR probes as a diagnostic indicator for drowning; the Leicester experience.
}

Guy N. Rutty, Carina J. Bradley, Mike JP. Biggs, Frances E. Hollingbury, Stuart J. Hamilton, Roger D.G. Malcomson, Christopher W. Holmes

G.N. Rutty, M.J.P. Biggs, F.E. Hollingbury, S.J. Hamilton. East Midlands Forensic Pathology Unit, University of Leicester, Robert Kilpatrick Building, Leicester, LE2 7LX, United Kingdom

C.J. Bradley, C.W. Holmes ( $\square)$. Clinical Microbiology, empath Pathology Services, University Hospitals of Leicester NHS Trust, Leicester Royal Infirmary, Leicester, LE1 5WW United Kingdom. Email Christopher.W.Holmes@uhl-tr.nhs.uk

R.D.G. Malcomson. Histopathology, empath Pathology Services, University Hospitals of Leicester NHS Trust, Leicester, LE1 5WW, United Kingdom

G.N. Rutty and C.J. Bradley contributed equally to this work.

\section{Conflict}

None

Keywords

Forensic, autopsy, drowning, bacterioplankton, real-time PCR

\section{Abstract}

Bodies found immersed in water can pose difficulties to the investigating authorities. Pathologists may be assisted with the diagnosis by the use of tests such as the analysis for diatoms or the levels of strontium in the blood, although there is a recognised level of uncertainty associated with these tests. Recent work from Japan has shown that using molecular approaches, most recently real-time polymerase chain reaction (PCR) assays with TaqMan probes for bacterioplankton, it is possible to undertake rapid, less laborious, high throughput tests to differentiate freshwater from marine bacterioplankton and in doing so provide a molecular diagnostic test to assist in the diagnosis of drowning. We report the experiences of a United Kingdom forensic pathology unit in the use of this PCR based system for the diagnosis of drowning. We applied this technique to 20 adult and child cadavers from 4 bath, 12 freshwater, 2 brackish and 2 salt water scenes both from within the United Kingdom and abroad. Drowning was concluded to be the cause of death in 16 of these 20 cases and the PCR method supported this conclusion in 12 of these 16 cases. The PCR did not provide evidence of drowning in the four cases where death was from other causes. We illustrate that this PCR method provides a rapid diagnostic supportive test for the diagnosis of drowning that can be applied to United Kingdom autopsy practice. 


\section{Introduction}

Bodies found immersed in water can pose difficulties to the investigating authorities. The forensic pathologist must assist in determining whether the deceased was alive or dead prior to entering the water and, if alive, whether the primary cause of death was that of so-called "wet" drowning. All too often, the resulting conclusions may rely on a diagnosis of exclusion [1]. Macroscopic features of drowning such as the classic plume of white froth from the nose or mouth, overinflated, crepitant lungs, pulmonary oedema or water in the stomach may be present or absent depending upon the individual case [2]. Pathologists may be assisted with the diagnosis by the use of tests such as the analysis for diatoms [3] or the levels of strontium in the blood [4] although there is a recognised level of uncertainty associated with these tests.

In 1990 Mishul'skii suggested that the examination of blood for Pseudomonas putida and Pseudomonas fluorescens could assist in the diagnosis of freshwater drowning [5]. In 2001 a meeting abstract in the Japanese language proposed the use of water borne bacterial DNA for diagnostic use [6]. This work was expanded upon by Lucci et al., who again studied the presence of faecal bacteria in water environments $[7,8]$. Although their work appeared promising, doubts still existed in relation to the use of faecal bacteria for the diagnosis of drowning [9]. Following on from this early work, a series of papers has been presented within the peer reviewed literature from Japan concerning the investigation of bacterioplankton, first in blood and latterly in tissue samples for the diagnosis of drowning [10-17]. This work has shown that using molecular approaches, most recently real-time PCR assays with TaqMan probes for bacterioplankton, it is possible to undertake rapid, less laborious, high throughput tests to differentiate freshwater from marine bacterioplankton and in doing so provide a molecular diagnostic test to assist in the diagnosis of drowning [18].

Considering the work from Japan we have applied the PCR technique reported by Uchiyama et al., [16] to 20 cases of bodies retrieved from or adjacent to water and examined by the East Midlands Forensic Pathology Unit (EMFPU), Leicester, United Kingdom (UK). Using tissue samples obtained from three body cavities from both adult and child cadavers found in indoors and outdoors scenes, including 4 bath, 12 freshwater, 2 brackish and 2 salt water scenes both from within the UK and abroad we report, for what we believe is the first time from the UK, our experiences in the use of this PCR based system for the diagnosis of drowning. We agree with the conclusions of Uchiyama et al., that the use of this test assists with the rapid diagnosis of drowning to the extent that we have adopted this test as routine in the practice of the EMFPU in the investigation of cases of suspected drowning.

\section{Materials and method}

Twenty consecutive cases of bodies found in water or adjacent to water where the possibility of drowning was raised, which were referred to the EMFPU and authorised for invasive autopsy examination by HM Coroner, were included in this service evaluation study. These included both adults and children and bodies repatriated from overseas. There were no exclusion criteria.

\section{Samples}

In all cases a reference water sample from the point where the body was recovered was requested. Where a sample could not be obtained, for example when a body was repatriated from abroad, a sample of stomach contents was submitted for examination. On one occasion, the body bag was found to contain a quantity of water which had arisen during the body recovery process. A sample was submitted from the water in the bag. 
In all cases tissue samples were obtained under as sterile sampling procedures as possible. The first sample was taken from the brain on opening of the skull bones and reflection of the dura (except for cases 1 and 2). The second sample was taken from one of the lungs on opening of the chest cavity (except for cases 13 and 18). The third sample was taken from the spleen on opening of the peritoneal cavity and prior to the removal of any of the other organs (except for case 5). Finally, again prior to removal of the other organs, a sample of kidney was obtained (except for case 18). Liver samples were also taken in some cases $(5,11$, and 13-15). For each case a new scalpel blade and a clean, different pair of forceps were used for sampling and tissue handling. All samples were placed into separate sterile universal containers with no preservative. These were placed into a refrigerator at $4^{\circ} \mathrm{C}$ before being processed in the Clinical Microbiology laboratory at Leicester Royal Infirmary.

\section{Autopsy}

A full invasive autopsy was undertaken by a forensic pathologist, trainee or consultant, working to national forensic pathology guidelines in all cases [19]. The subsequent report was retrospectively interrogated for the age and gender of the deceased, date and time pronounced dead, date of autopsy, date of laboratory investigation and cause of death.

\section{DNA Isolation}

Initial treatment of samples for nucleic acid extraction varied depending on type. Up to $50 \mathrm{mg}$ of each tissue sample (<10 mg of spleen) was aseptically transferred to a MagNA Lyser Green Beads tube (Roche Diagnostics Ltd, Mannheim, Germany) containing $500 \mu \mathrm{L}$ of a 1:1 solution of Bacteria Lysis Buffer (BLB; Roche) and phosphate buffered saline (PBS) and homogenised for 30 seconds at $6000 \mathrm{rpm}$ in a MagNA Lyser instrument (Roche). Body fluids, including viscous stomach content samples, were prepared by combining $200 \mu \mathrm{L}$ of fluid with an equal volume of BLB. Water samples from the source were prepared by centrifuging $10 \mathrm{~mL}$ of the neat water at $4500 \times \mathrm{g}$ and reconstituting any pellet formed in $200 \mu \mathrm{L}$ of the supernatant plus $200 \mu \mathrm{L}$ of BLB. All sample types were then digested with the addition of Proteinase $\mathrm{K}$ solution (1:20 of final sample volume) at $65^{\circ} \mathrm{C}$ for a minimum of 30 minutes until any solid material had completely lysed. A final digestion step at $99^{\circ} \mathrm{C}$ for 10 minutes completed the tissue lysis. To reduce the risk of carry-over contamination between the samples, each case was processed individually and a fresh set of disposable forceps and scalpel were used to process each tissue. The closed tissues and body fluids were processed first, followed by the lung tissue before handling the water samples last. A negative control sample consisting of molecular grade water spiked with carrier RNA (CRNA) was used through the extraction (treated in the same way as body fluid samples) in order to identify reagent contamination during this process.

Following completion of the lysis step, $400 \mu \mathrm{L}$ of each of the samples was processed using the MagNA Pure Compact instrument (Roche) with the Nucleic Acid isolation Kit I (Roche) and the DNA_Bacteria_V3_2 protocol, eluting into a final volume of $50 \mu \mathrm{L} .5 \mu \mathrm{L}$ of an in-house preparation of T4 bacteriophage was added to each sample during the extraction protocol and used as an internal control (IC) to detect PCR inhibition or extraction failure. The DNA isolated from the samples was stored at $4^{\circ} \mathrm{C}$ until the PCR could be performed which was within 24 hours of extraction.

\section{PCR investigations}

The purified DNA solution from each sample was tested in duplicate for the presence of eight bacterioplankton DNA targets by TaqMan PCR. Three triplex primer-probe sets to detect species of Aeromonas, Vibrio and Photobacterium [18] (NED-labelled probes were substituted with VIC labelled probes for thermocycler compatibility), and one set for detection of the IC (forward primer $5^{\prime}$ AGCACAAATGGTGAGCACAG-3', reverse primer 5'-CACCCGCCCTGTATGATATG-3' and probe ROX-5'- 
TCGAGGCATGGAATGGTACTGGTGT-3'-BHQ2) were used to test all samples regardless of the water type at the location of the body. Each reaction contained $1 x$ SensiFast ${ }^{\text {TM }}$ Probe No-ROX mix (Bioline Reagents Ltd, London, UK), 8 pmol of each primer, 4 pmol of each probe and $5 \mu \mathrm{L}$ of each sample or appropriate positive or negative PCR control, in a total volume of $20 \mu \mathrm{L}$. Genomic DNA of each target bacterioplankton species (a gift from Dr E. Kakizaki) was used as positive control material and optimised to amplify near to the end of the PCR cycling. Amplification was performed on a RotorGene Q real-time PCR system (QIAGEN, Manchester, UK) using the cycling protocol: $95^{\circ} \mathrm{C}$ for 5 minutes followed by 40 cycles of $95^{\circ} \mathrm{C}$ for 10 seconds and $58^{\circ} \mathrm{C}$ for 50 seconds. Amplification results were accepted only if the positive controls were within the expected range, the negative template control and negative extraction controls were negative and the IC was within the expected range for each extracted sample. If the IC was not within the expected range in any sample the test was repeated with a 1:10 dilution of the DNA extract and the negative extraction control in parallel.

\section{Assay analytical sensitivity and linearity}

Analytical sensitivity and linearity of the PCR assay were assessed by testing in triplicate 10-fold serial dilutions of purified genomic DNA from each target bacterioplankton species. DNA concentrations tested ranged from $1 \mathrm{ng} / \mu \mathrm{L}$ to $0.1 \mathrm{pg} / \mu \mathrm{L}$. Standard curves, correlation coefficients and reaction efficiency values were calculated for each target using the Rotor-Gene $Q$ software version 2.1 (QIAGEN).

\section{Data Analysis}

The results from the PCR were compared to the pathologist's report for each case. The pathologist's final conclusion was recorded along with a number of possible contributing factors, including: location and time of year in which the body was recovered; whether the body was found immersed or near to water; the length of time the body was in the water; the duration between body recovery and post mortem examination; age; gender; and the level of putrefaction, injuries and disease of the body.

\section{Results and Discussion}

The diagnosis of drowning, especially in a body that has been in water for a prolonged period of time, may pose difficulties to the investigating pathologist [1]. Few, if any, of the pathognomonic features of drowning may be present and laboratory tests may not provide sufficient specificity. Various biological and thanato-chemical markers have been proposed within the peer reviewed literature of which one of the best known is the search for diatoms [8]. However there remains a problem related to the general acceptance of these tests [8].

In the 2009 paper by Kakizaki et al., [14], the authors make reference to a Japanese language abstract from 2001 [6], in which they proposed the use of a molecular method for the diagnosis of drowning. However, it took several years to build upon this proposal. Although a PCR method was proposed in 2005 [20] for the investigation of water borne bacteria and drowning, the next major communication arose in 2007. Building upon the proposal of Mishul'skii [5] for the use of bacteria to investigate cases of drowning, Lucci et al., $[7,8]$ presented two papers proposing the investigation for the presence of faecal coliforms and streptococci in cadaver cardiac blood samples to assist in the diagnosis of drowning. They inform us that such organisms are present in faecal contamination of freshwater and, as they are smaller than diatoms, they can enter the lungs and thus the circulation to be distributed throughout the body during the process of drowning in the presence of an active circulation [8]. As those who survive drowning can go on to develop pneumonia and septicaemia from such organisms, this was a logical observation [8]. This work also presented the finding that although passive diffusion of water borne bacteria into the lungs can occur after death, circulatory dissemination did not occur. 
Shortly after this work, a series of papers was presented from Japan considering the investigation for both marine and freshwater bacteria. The first in 2008 [16] Kakizaki et al., again highlighted that marine bacterioplankton are smaller than diatoms and thus can enter the body during drowning. As putrefactive bacteria are mainly Gram positive and cytochrome oxidase test (COT) negative, the identification of COT positive marine bacteria could be used to support a diagnosis of saltwater drowning. Initially working with blood, PCR detection of Aeromonas species was shown to be present in $84 \%$ of freshwater drowning cases [17]. A case report was then presented using tissue samples instead of blood to demonstrate the use of the test to show that a body found in saltwater had drowned in freshwater [13]. Later papers showed $91 \%$ of those that drowned were positive by PCR for bacterioplankton [11]. They put forward that post-mortem invasion and dissemination did not readily occur and found that bacterioplankton could not be detected in those bodies found near water or who had died and then entered water. In the most recent paper, Uchiyama et al., presented a high throughput PCR system using TaqMan probes which could be undertaken in 4 to 6 hours, and which identified bacterioplankton in $84 \%$ of blood or organs of those who drowned [18] compared to $44 \%$ diatom identification in the same cases. The negative cases were discussed as potentially having been affected by low numbers of organisms at the site of drowning, low water temperature and a short post-mortem period.

We have considered the research presented within these authors' work, most recently that of Uchiyama et al., and applied this latest PCR method to 20 consecutive cases of bodies recovered from water, both adults and children. We have made the following observations.

\section{Analytical sensitivity and linearity of the real-time PCR}

The panel of multiplex real-time PCR assays used in this study has been adapted from one previously described by Uchiyama et al., [18]. We assessed the sensitivity and linearity of each PCR within the panel to ensure the modifications had no effect on assay performance. All PCR assays were linear over the full range tested ( $0.5 \mathrm{pg}$ to $5 \mathrm{ng}$ ), had linear regression values $>0.990$ and had amplification efficiencies in the range $99-122 \%$ indicating that the linearity and analytical sensitivity were equal to those of the original assay.

\section{Bodies in or associated with freshwater}

Twelve bodies were recovered from sources of freshwater, including: 4 from rivers; 4 from canals; 2 from lakes; and 2 from roadside ditches (cases 1-12). Ten of the cases were immersed in the water on recovery but two were not immersed (cases 1 and 4). Case 1 was recovered from near a river which had been flooded and case 4 had been hospitalised at the time of death but had recently been recovered unconscious from a river. The duration of the bodies' exposure to the water ranged from approximately 5 minutes to 40 days with all post mortem examinations being completed within 4 days of recovery.

In eleven of the twelve cases, drowning was considered the cause of death according to the pathologists' reports. For the other case (4) the cause of death was reported as cardiac arrest by the pathologist; this was also one of the cases which had not been found immersed in water. Of the eleven cases where drowning was considered the cause of death, the bacterioplankton PCR supported this conclusion in nine cases. The PCR results for cases 7 and 12 were not supportive of drowning as bacterioplankton was detected in the lung tissue and water samples only, but not in the closed tissues. In both of these cases, assuming that the decedents were alive but not necessarily conscious, it would appear that they had not ingested as much water as would normally be expected when drowning. So-called "dry drowning" could explain this observation. Five of the cases showed none or only minor injuries and no signs of natural disease. Five cases showed non-penetrating head injuries which, therefore, have not have affected the PCR results (cases 2, 4, 7, 9 and 12). Case 8 
showed narrowing of the cardiac blood vessels and case 10 showed an existing upper respiratory tract infection (URTI) with Influenza A virus. None of the injuries or diseases encountered appears to have affected the samples tested or the results of the PCR, including case 4 which, although the body had been immersed in water prior to death and a significant head injury was noted, there was no sign of entry of bacterioplankton into the circulation via the wound [21]. Considering that some of the bodies had only been exposed to the water for a matter of minutes (e.g. case 10), it was still possible to produce a reliable PCR result indicating that bacterioplankton DNA was present in at least some of the closed tissues.

Bodies in or associated with saltwater

Two bodies were recovered from marine water. Both were repatriated from abroad: one from East Asia; and one from Europe (cases 13 and 14 respectively). Both bodies were considered to have been in the water for less than 12 hours when they were recovered but there was a significant delay between recovery of the body and post-mortem examination due to the repatriation process. The sampling was therefore performed 15 days and 8 days post-recovery, respectively. No water samples were available for testing, however the stomach contents were used as a substitute water control for case 13. No adverse effects were noted from the PCR results obtained in case 13 with a number of the marine bacterioplankton targets being detected, supporting the conclusion of drowning. However, the body from case 14 had been embalmed and all of the tissue samples including the lung sample had no detectable bacterioplankton DNA present.

There were initial concerns that embalming could affect the test by inhibiting the PCR. However, for case 14 , the internal control was detectable within the expected range suggesting that PCR inhibition did not occur. Subsequent to the end of this service evaluation study, we have examined another case of suspected saltwater drowning from abroad. The body had been subject to previous autopsy and embalming. By sampling an organ not examined at the first autopsy i.e. testis, as well as areas of the kidney and lung not examined at the first autopsy, and fluid from the body cavity which was not in contact with the organs from the first autopsy examination, we found the samples to be positive for marine bacterioplankton, thereby supporting the clinical impression of drowning. However, our experience of testing embalmed tissues is limited therefore further investigations are needed to understand the effect of embalming on microbial DNA in human tissue.

\section{Bodies in or associated with brackish water}

Two bodies were recovered from immersion in sources of brackish water which were tidal rivers near to the coast (cases 15 and 16). One body was in an advanced stage of decomposition, having been in the water for more than two weeks (case 15) and the PCR results were supportive of drowning in brackish water due to the mixture of freshwater and marine water bacterioplankton DNA detected in the closed tissues and lung samples. The other body was moderately decomposed having been in the water for approximately 4 days (case 16) and the PCR results were supportive of freshwater drowning due to the presence of freshwater bacterioplankton DNA in the closed tissues and lung samples. Neither body showed significant signs of injury or natural disease which could have affected the results.

For both cases a reliable water control sample was not available. For case 15 , a water sample was taken from the recovery site but not until two weeks after retrieval of the body. Different types of bacterioplankton DNA were detected in this water compared to the tissue samples suggesting either drowning at a different location, or more likely, that due to the delay in collecting the water sample, the bacterial composition of the tidal water had changed in the time since the body was recovered. For case 16, although there was no water control sample, a sample of stomach contents was tested and found to contain the same types of bacterioplankton DNA as the tissues. In this case, only 
Aeromonas species DNA was detected, suggesting that the person had drowned in a source of freshwater and not in brackish water as had been suspected. As a sample of water was not available for testing from the recovery site, it was not possible to determine the bacterioplankton composition at this location.

\section{Bodies in or associated with baths}

Four cases involved deaths associated with bath water (cases 17-20). In three of the four cases, a body was found immersed in the water with an estimated exposure of less than one hour (cases 1719). In case 20 , the body was found adjacent to the bath water and the exact exposure could not be determined. No significant injuries were recorded in any of these cases.

In case 17, bacterioplankton DNA was not detected in any of the closed tissues and lung. No bath water was available for testing but a sample of fluid from the stomach was tested and also found to contain no detectable bacterioplankton DNA. The pathologist concluded drowning as a cause of death due to physical indicators but the PCR was unable to support this diagnosis due to the absence of detectable bacterioplankton DNA in all samples and the PCR results were therefore recorded as inconclusive.

Similarly, bacterioplankton DNA was not detected in any closed tissues, lung tissue or stomach contents for case 18. The fluid from the stomach was considered to be inhibitory to the PCR as the internal control did not amplify and this result was discounted. This was likely caused by high ethanol content in the stomach which had been indicated on the toxicology report. No bath water was available but a sample of the water from the hot and cold water taps was tested and the cold water was found to be very weakly positive for Aeromonas species DNA. The pathologist found possible signs of seizure in this case which suggested an alternative diagnosis from drowning as the cause of death.

For case 19, bacterioplankton DNA was not detected in any of the closed tissues but was detected in the lung tissue. No bath water was available to confirm the origin of this DNA but, even without this, the PCR results supported the diagnosis that drowning had not occurred. The individual was known to suffer from a chromosomal microdeletion syndrome and the pathologist found signs of cardiac hypertrophy during the post-mortem examination which supported an alternative diagnosis from drowning.

Similarly, case 20 showed no detectable bacterioplankton DNA in the closed tissues or in the lung tissue but a bath water sample was tested and found to contain Aeromonas species DNA. The PCR results therefore supported the diagnosis that drowning did not occur which complied with the pathologist's conclusion, with an alternative cause of death being stated as thrombotic occlusion of the coronary artery.

Whereas evidence suggests that diatom testing may be of use in bathwater drowning cases [22], the utility of this PCR test is less clear. When previously used in Japan, no bacterioplankton were detected in tissue samples from three bodies discovered in baths but no samples of bathwater were tested [18]. It is not known if bacterioplankton are normally present in detectable levels in domestic water supplies in the UK in numbers sufficient to be detected by this assay, if translocated into tissues. Aeromonas species DNA was detected in two of three domestic water samples tested in this study, and was at a very low concentration in one of these. The domestic water treatment process is designed to reduce significantly the number of bacteria and, although the treatment process efficiently kills bacteria, it is not designed to remove DNA. This PCR assay does not distinguish between live and non-viable cells so it should be possible to detect low levels of DNA released from dead bacterioplankton in water samples. This DNA is unlikely to be subject to the same processes as 
live bacteria if inhaled by a drowning victim and therefore should not be detectable in tissues of closed organs.

\section{Other findings of note}

Kakizaki et al., [11] have demonstrated that post-mortem bacterial invasion of tissues does not readily occur, even in highly decomposed bodies. It was not possible to evaluate these findings in our study as the pathologist concluded drowning as the cause of death for all cases involving significantly decomposed bodies. All such cases were supported by the detection of bacterioplankton DNA in the closed tissues, but we cannot rule out post-mortem invasion. In comparison, we identified five cases where the water exposure was estimated to be less than 12 hours and post-mortem invasion was unlikely, but also showed bacterioplankton DNA was detectable in all tissues, suggesting translocation from the lung was the likely source.

For the four cases where the pathologists concluded drowning as the cause of death, but the PCR did not support drowning or was considered inconclusive, a number of explanations could be considered. In cases 7 and 12, there is a possibility that both victims were unconscious on entering the water and therefore did not ingest a significant amount of fluid (dry-drowning). The body in case 14 had been embalmed with possible degradation of the target DNA resulting from this process. Case 17 was a bath related incident and with no water sample to test, it is possible that there was no detectable bacterioplankton present in the water source resulting in no reliable data from the PCR test.

\section{Limitations of study}

Although the PCR has shown to be a good indicator of drowning in a number of cases, it does still have limitations which mean that it should always be interpreted in context with the other situational and pathological findings of an investigation.

It could be criticised that we have no non-drowning control cases in our study. However one would not expect these bacteria to be part of the human microbiome. All the tissues we have tested (excluding the lung) should ordinarily be sterile. The possibility that the presence of these bacteria in the normally sterile tissues had occurred as part of an infection could be considered, as infections with all three genera of bacteria have been documented. Such infections are usually associated with small injuries in water or caused by objects that have been in water where local multiplication of the bacteria occurs in the wound, followed by haematogenous spread, although they are comparatively rare. Considering the problem reported in relation to drug redistribution from the stomach after death we were conscious that we could be criticised for not considering the possibility of postmortem circulatory distribution. However the work of Lucci et al., [8] supports that this does not occur. We were mindful of this possibility and interpreted the results in the context of the clinical circumstances of the case and the autopsy findings.

In some of the cases a water sample from the site of immersion was not available. In these cases watery fluid from the stomach was used as a substitute on the basis that it is recognised that during the process of wet drowning, water can be taken into the stomach. The stomach contents of a living person may contain DNA of these bacteria if they had recently swallowed water. However having said this it is reasonable to consider that the source of the bacteria detected in stomach contents in a case of suspected drowning is due to swallowing water during the drowning process rather than drinking bacteria containing fresh, brackish or salt water prior to death. Thus the water in the stomach should be representative of the water at the point of immersion.

Another source of $V$. fischeri DNA could be if the person had eaten seafood as $V$. fischeri is a commensal organism of squid. Even if cooked, DNA from this source could be detected and thus it is advisable to try and seek a history related to the last meal eaten to exclude this source of DNA. 
Although uncommon, it is possible for bacteria such as Aeromonas species to enter the body via significant wounds, causing false-positive results. This would need to be taken into consideration while interpreting the results when significant injuries are present [21].

Due to the high DNA content of spleen tissue, these samples were sometimes found to be inhibitory and therefore required a smaller amount of tissue to be sampled, increasing the risk of a falsenegative result. Without positive PCR results from the lung tissue and/or water sample, failure to detect bacterioplankton DNA in the closed tissues could not be used as evidence that an individual did not drown. This was particularly a problem for bodies found in bathwater.

During this study, it was noted that the PCR results obtained from the water samples generally showed later PCR amplification than for the other sample types suggesting that, despite concentrating the water samples before testing, the bacterioplankton concentration in the water was lower than in the other sample types (often by over 100 -fold). This could possibly be due to some on-going growth of the bacteria within the tissues, but this cannot be further characterised by the results in this study.

Although the results of this study suggest that the range of bacterioplankton species targeted by the PCR are appropriate for the water sources in which drowning victims are likely to be found, the relatively narrow range of eight target species is a potential limiting factor. Evidence suggests that other species of bacteria present in water are translocated into the organs during drowning [10]. In cases where bodies are found in water where the species targeted by this PCR are absent, other bacterial species could be used to provide evidence for the cause of death. A more broad-based approach, such as microbiome profiling using next-generation sequencing [10], although likely to have its own limitations, has the potential to overcome this disadvantage of targeted PCR.

\section{Conclusions}

Despite the limitations noted above, we are of the opinion that the PCR method described by Uchiyama et al., provides a rapid (4-6 hours), potentially high throughput, supportive test for the diagnosis of drowning that can be readily applied to cases undertaken in the United Kingdom. We report that, in those cases where the pathologist suspected a diagnosis of drowning based on the autopsy findings and supportive clinical history, all such cases yielded valuable PCR findings including a case we report from a drowning in a domestic bath. We are of the opinion that our work adds to that of Uchiyama et al., to encourage the use of this test for the diagnosis of freshwater, brackish and saltwater drowning.

\section{Acknowledgments}

We wish to thank Professor Nobuhiro Yukawa and Dr Eiji Kakizaki for their assistance with this study. They provided us with advice related to the test they had designed and with the provision of the bacterial genomic DNA for our research.

\section{References}

1. Piette MHA, De Letter EA. Drowning: still a difficult autopsy diagnosis. Forensic Sci Int 2006; 163: 1-9.

2. Yukawa N, Kakizaki E, Kozawa S. Diatom and laboratory tests to support a conclusion of death by drowning. In, Essentials of autopsy practice. Innovations, updates and advances in practice. Ed, Rutty GN. 2013, Springer, London, pages 1-36 .

3. Peabody AJ. Diatoms and drowning - a review. Med Sci Law 1980; 20: 254-61. 
4. Azparren JE, Vallejo G, Reyes E, Herranz A, Sancho M. Study of the diagnostic value of strontium, chloride, haemoglobin, and diatoms in immersion cases. Forensic Sci Int 1998; 91: 123-32.

5. Mishul'skii AM. The use of bacteriological analysis of the blood in a diagnosis of death by drowning. Sud med Ekspert 1990; 33: 26-8.

6. Kakizaki E, Seo Y, Matsuda H, Kozawa S, Takahama K. Molecular biological approach to the aquatic bacteria in drowning victim. Jpn J Leg Med, Volume 55, Number 3, November 2001.

7. Lucci A, Cirnelli A. A microbiological test for the diagnosis of death by drowning. Forensic Sci Int 2007; 168: 34-6.

8. Lucci A, Campobasso CP, Cirnelli A, Lorenzini G. A promising microbiological test for the diagnosis of drowning. Forensic Si Int 2008; 182: 20-6.

9. Woodford NWF, Bollmann MD. Comment on "A microbiological test for the diagnosis of death by drowning" by A Lucci and A Cirnelli. Forensic Sci Int 2008; 179: e79.

10. Kakizaki E, Ogura Y, Kozawa S, Nishida S, Uchiyama T, Hayashi T, Yukawa N. Detection of diverse aquatic microbes in blood and organs of drowning victims: first metagenomic approach using high-throughput 454-pyrosequencing. Forensic Sci Int. 2012; 220:135-46.

11. Kakizaki E, Kozawa S, Imamura N, Uchiyama T, Nishida S, Sakai M, Yukawa N. Detection of marine and freshwater bacterioplankton in immersed victims: Post-mortem bacterial invasion does not readily occur. Forensic Sci Int. 2011; 211:9-18.

12. Kakizaki E, Kozawa S, Matsuda H, Muraoka E, Uchiyama T, Sakai M, Yukawa N. In vitro study of possible microbial indicators for drowning: Salinity and types of bacterioplankton proliferating in blood. Forensic Sci Int. 2011; 204:80-7.

13. Kakizaki E, Kozawa S, Matsuda H, Muraoka E, Uchiyama T, Sakai M, Yukawa N. Freshwater bacterioplankton cultured from liver, kidney and lungs of a decomposed cadaver retrieved from a sandy seashore: possibility of drowning in a river and then floating out to sea. Leg Med (Tokyo). 2010; 12:195-9.

14. Kakizaki E, Kozawa S, Tashiro N, Sakai M, Yukawa N. Detection of bacterioplankton in immersed cadavers using selective agar plates. Leg Med (Tokyo). 2009; 11 Suppl 1:S350-3.

15. Kakizaki E, Kozawa S, Sakai M, Yukawa N. Bioluminescent bacteria have potential as a marker of drowning in seawater: two immersed cadavers retrieved near estuaries. Leg Med (Tokyo). 2009; 11:91-6.

16. Kakizaki E, Takahama K, Seo Y, Kozawa S, Sakai M, Yukawa N. Marine bacteria comprise a possible indicator of drowning in seawater. Forensic Sci Int. 2008; 176:236-47.

17. Aoyagi M, Iwadate K, Fukui K, Abe S, Sakai K, Maebashi K, Ochiai E, Nakamura M A novel method for the diagnosis of drowning by detection of Aeromonas sobria with PCR method. Leg Med (Tokyo). 2009; 11:257-9.

18. Uchiyama T, Kakizaki E, Kozawa S, Nishida S, Imamura N, Yukawa N. A new molecular approach to help conclude drowning as a cause of death: simultaneous detection of eight bacterioplankton species using real-time PCR assays with TaqMan probes. Forensic Sci Int. 2012; 222: 11-26.

19. Code of practice and performance standards for forensic pathology in England, Wales and Northern Irelandhttp://www.rcpath.org/Resources/RCPath/Migrated\%20Resources/Documents/G/G131_ CoPForensicPathology_Oct12.pdf (last visited Sept 2014).

20. Suto $M$, Kato $N$, Abe $S$, Nakamura $M$, Tsuchiya R, Hiraiwa K. Detection of bacterial genes by PCR and its application to practical cases of death by drowning. Res Pract Forens Med 2007; 50: 73-9 [Japanese with English abstract]. 
21. Mahabeer Y, Khumalo A, Kiratu E, Mlisana K. Posttraumatic Brain Abscess Caused by Aeromonas hydrophila. J Clin Microbiol 2014; 52: 1796-7.

22. Ago $K$, Hayashi T, Ago $M$, Ogata $M$. The number of diatoms recovered from the lungs and other organs in drowning deaths in bathwater. Leg Med (Tokyo). 2011; 13: 186-90.

\section{Tables}

Table 1. Demographic data of the twenty service evaluation study cases. NSI: No significant injury or disease.

Table 2. Individual PCR results for all specimens analysed in this study. $C_{T}$ values represent mean of duplicate results except where marked with \pm which indicates one replicate positive and the other negative, due to the presence of DNA around the limit of detection of the test. These results were considered negative if this could not be replicated on repeat. Inconclusive: No definitive evidence of bacterioplankton in any of the samples including lung and water samples. B: Brain. St: Stomach Contents. K: Kidney. W: Water. Li: Liver. C: Chest cavity fluid. S: Spleen. WB: Water from body bag. L: Lung. ND: Not Detected. 


\begin{tabular}{|c|c|c|c|c|c|c|c|c|c|c|}
\hline $\begin{array}{l}\text { Case } \\
\text { No }\end{array}$ & $\begin{array}{l}\text { Final Cause of Death (Based on circumstantial } \\
\text { and pathological findings) }\end{array}$ & $\begin{array}{c}\text { Age } \\
\text { (years) }\end{array}$ & Gender & $\begin{array}{l}\text { Body Location } \\
\text { (Type of water) }\end{array}$ & $\begin{array}{l}\text { Body Immersed/ } \\
\text { Not at retrieval }\end{array}$ & $\begin{array}{c}\text { Estimated } \\
\text { duration in water }\end{array}$ & $\begin{array}{l}\text { Duration from } \\
\text { recovery to autopsy }\end{array}$ & $\begin{array}{c}\text { Putrefaction/ } \\
\text { injury/natural disease }\end{array}$ & Season & BP PCR Result \\
\hline 1 & Drowning & 33 & M & Freshwater & Not Immersed & 40 days & 3 days & Decomposed - NSI & Winter & $\begin{array}{l}\text { Freshwater } \\
\text { drowning }\end{array}$ \\
\hline 2 & Drowning & 21 & M & Freshwater & Immersed & 21 days & 3 days & Moderate - Possible head injury & Spring & $\begin{array}{l}\text { Freshwater } \\
\text { drowning }\end{array}$ \\
\hline 3 & Drowning & 36 & M & Freshwater & Immersed & 1 hour & 2 days & Moderate -NSI & Winter & $\begin{array}{l}\text { Freshwater } \\
\text { drowning }\end{array}$ \\
\hline 4 & $\begin{array}{l}\text { Cardiac arrest with hypoxic brain injury and } \\
\text { early stage bronchopneumonia }\end{array}$ & 50 & M & Freshwater & Not Immersed & 5 mins & 2 days & $\begin{array}{l}\text { Minor - Significant head injury but } \\
\text { not full scalp thickness }\end{array}$ & Winter & $\begin{array}{l}\text { Inconclusive - No } \\
\text { evidence of BP }\end{array}$ \\
\hline 5 & Drowning & 14 & M & Freshwater & Immersed & 2 weeks & $<12$ hours & Advanced decomposition - NSI & Autumn & $\begin{array}{l}\text { Freshwater } \\
\text { drowning }\end{array}$ \\
\hline 6 & Drowning & 51 & M & Freshwater & Immersed & 13 days & $<24$ hours & $\begin{array}{c}\text { Moderate: Extensive } \\
\text { decomposition of brain - NSI }\end{array}$ & Spring & $\begin{array}{l}\text { Freshwater } \\
\text { drowning }\end{array}$ \\
\hline 7 & Drowning & 63 & M & Freshwater & Immersed & $<30$ hours & 12 hours & $\begin{array}{l}\text { Minor - Spinal injury \& deep head } \\
\text { laceration but no skull injury }\end{array}$ & Summer & $\begin{array}{l}\text { Drowning not } \\
\text { supported }\end{array}$ \\
\hline 8 & Drowning & 57 & M & Freshwater & Immersed & 1 day & 4 days & $\begin{array}{c}\text { Minor - Narrowing of blood vessel } \\
\text { to heart }\end{array}$ & Summer & $\begin{array}{l}\text { Freshwater } \\
\text { drowning }\end{array}$ \\
\hline 9 & Drowning (alcohol intoxication) & 49 & $\mathrm{~F}$ & Freshwater & Immersed & $<12$ hours & 2 days & $\begin{array}{l}\text { Minor - Head lacerations, no skull } \\
\text { fracture }\end{array}$ & Spring & $\begin{array}{l}\text { Freshwater } \\
\text { drowning }\end{array}$ \\
\hline 10 & Drowning & 7 & $\mathrm{~F}$ & Freshwater & Immersed & $<15$ mins & 3 days & $\begin{array}{l}\text { Minor - URTI with Influenza A but } \\
\text { NSI }\end{array}$ & Spring & $\begin{array}{l}\text { Freshwater } \\
\text { Drowning }\end{array}$ \\
\hline 11 & Drowning (acute alcohol intoxication) & 56 & M & Freshwater & Immersed & $<12$ hours & $<24$ hours & Minor - NSI & Summer & $\begin{array}{l}\text { Freshwater } \\
\text { drowning }\end{array}$ \\
\hline 12 & Drowning & 33 & M & Freshwater & Immersed & $<6$ hours & 3 days & Minor - Minor head injury & Spring & $\begin{array}{l}\text { Drowning not } \\
\text { supported }\end{array}$ \\
\hline 13 & Drowning & 26 & M & Marine & Immersed & $<12$ hours & 15 days & Moderate - NSI & $\begin{array}{l}\text { Winter } \\
\text { (abroad) }\end{array}$ & $\begin{array}{l}\text { Marine water } \\
\text { drowning }\end{array}$ \\
\hline 14 & Drowning & 66 & $\mathrm{~F}$ & Marine & Immersed & $<12$ hours & 8 days & Body embalmed - NSI & $\begin{array}{l}\text { Spring } \\
\text { (abroad) }\end{array}$ & $\begin{array}{l}\text { Inconclusive - No } \\
\text { evidence of BP }\end{array}$ \\
\hline 15 & Drowning & 32 & M & Brackish & Immersed & $>2-4$ weeks & 2 days & Advanced decomposition - NSI & Summer & $\begin{array}{l}\text { Brackish water } \\
\text { drowning }\end{array}$ \\
\hline 16 & Drowning (multiple drug intoxication) & 28 & M & Brackish & Immersed & 4 days & $<12$ hours & Moderate - NSI & Summer & $\begin{array}{l}\text { Freshwater } \\
\text { drowning }\end{array}$ \\
\hline 17 & Drowning & 93 & $\mathrm{~F}$ & Bath & Immersed & 1 hour & 3 days & Minor - NSI & Spring & $\begin{array}{l}\text { Inconclusive - No } \\
\text { evidence of BP }\end{array}$ \\
\hline 18 & Ethanol toxicity & 49 & $\mathrm{~F}$ & Bath & Immersed & $<30$ mins & 2 days & Minor - Possible seizure but NSI & Spring & $\begin{array}{l}\text { Inconclusive - No } \\
\text { evidence of BP }\end{array}$ \\
\hline 19 & $\begin{array}{l}\text { Unascertained (known chromosome 22q11 } \\
\text { microdeletion syndrome; cardiac hypertrophy) }\end{array}$ & 14 & $\mathrm{~F}$ & Bath & Immersed & $<15$ mins & 3 days & $\begin{array}{l}\text { Minor - Known DiGeorge } \\
\text { syndrome } 22 q 11 \text { but NSI }\end{array}$ & Winter & $\begin{array}{l}\text { Drowning not } \\
\text { supported }\end{array}$ \\
\hline 20 & $\begin{array}{l}\text { Thrombotic occlusion of coronary artery } \\
\text { (cocaine abuse) }\end{array}$ & 36 & $\mathrm{~F}$ & Bath & Not Immersed & $\begin{array}{l}\text { Undetermined } \\
\text { water exposure }\end{array}$ & $<24$ hours & Minor - NSI & Summer & $\begin{array}{l}\text { Drowning not } \\
\text { supported }\end{array}$ \\
\hline
\end{tabular}




\begin{tabular}{|c|c|c|c|c|c|c|c|c|c|c|c|}
\hline \multirow{3}{*}{ 峁 } & & & & & Real-Tim & PR Threshold Cross & Point $\left(C_{T}\right.$ & & & & \\
\hline & Sample & & Aeromon & & & Vibrio & & & Photobacte & & Assay \\
\hline & & aerA & gyrB & chiA & fischeri & parahaemolyticus & harveyi & damselae & leiognathi & phosphoreum & \\
\hline & $\mathrm{K}$ & 34.16 & 32.65 & 34.84 & ND & ND & ND & ND & ND & ND & \\
\hline & $\mathrm{S}$ & $38.62 \pm$ & ND & 35.99 & ND & ND & ND & ND & ND & ND & \\
\hline 1 & $\mathrm{C}$ & 29.35 & 28.30 & 28.98 & ND & ND & ND & ND & ND & ND & Freshwater \\
\hline & $\mathrm{L}$ & 20.25 & 18.47 & 18.38 & ND & ND & ND & ND & ND & ND & \\
\hline & W & 35.10 & 34.45 & 37.37 & ND & ND & ND & ND & ND & ND & \\
\hline & $\mathrm{K}$ & 31.22 & 35.63 & $36.71 \pm$ & ND & ND & ND & ND & ND & ND & \\
\hline ? & $\mathrm{s}$ & ND & ND & ND & ND & ND & ND & ND & ND & ND & Freshwater \\
\hline 2 & $\mathrm{~L}$ & 26.65 & 26.72 & 27.27 & ND & ND & ND & ND & ND & ND & drowning \\
\hline & St & 31.62 & 29.21 & 30.11 & ND & ND & ND & ND & ND & ND & \\
\hline & $B$ & ND & ND & ND & ND & ND & ND & ND & ND & ND & \\
\hline & $\mathrm{K}$ & 34.10 & 32.41 & ND & ND & ND & ND & ND & ND & ND & \\
\hline 3 & $\mathrm{~S}$ & ND & ND & ND & ND & ND & ND & ND & ND & ND & Freshwater \\
\hline & $\mathrm{L}$ & 17.19 & 15.39 & 15.57 & ND & ND & ND & ND & ND & ND & \\
\hline & St & 30.85 & 29.33 & ND & ND & ND & ND & ND & ND & ND & \\
\hline & B & ND & ND & ND & ND & ND & ND & ND & ND & ND & \\
\hline & $\mathrm{K}$ & ND & ND & ND & ND & ND & ND & ND & ND & ND & Inconclusive - \\
\hline 4 & $\mathrm{~s}$ & ND & ND & ND & ND & ND & ND & ND & ND & ND & Poor positive \\
\hline & $\mathrm{L}$ & ND & ND & ND & ND & ND & ND & ND & ND & ND & in Water \\
\hline & W & ND & $38.51 \pm$ & ND & ND & ND & ND & ND & ND & ND & \\
\hline & $B$ & 30.25 & 28.00 & 31.11 & ND & ND & ND & ND & ND & ND & \\
\hline & $\mathrm{K}$ & 25.99 & 23.61 & 24.55 & ND & ND & ND & ND & ND & ND & \\
\hline 5 & $\mathrm{Li}$ & 32.92 & 29.91 & 29.88 & ND & ND & ND & ND & ND & ND & Freshwater \\
\hline & $\mathrm{L}$ & 25.73 & 22.92 & 25.28 & ND & ND & ND & ND & ND & ND & \\
\hline & W & ND & ND & ND & ND & ND & ND & ND & ND & ND & \\
\hline & B & 27.66 & 25.48 & 27.58 & ND & ND & ND & ND & ND & ND & \\
\hline & $\mathrm{K}$ & 28.74 & 27.05 & 26.76 & ND & ND & ND & ND & ND & ND & \\
\hline 6 & $S$ & 29.87 & 29.22 & 29.00 & ND & ND & ND & ND & ND & ND & Freshwater \\
\hline & $\mathrm{L}$ & 20.49 & 19.11 & 20.62 & ND & ND & ND & ND & ND & ND & \\
\hline & W & 28.13 & 28.59 & 30.15 & ND & ND & ND & ND & ND & ND & \\
\hline & B & ND & ND & ND & ND & ND & ND & ND & ND & ND & \\
\hline & $\mathrm{K}$ & ND & ND & ND & ND & ND & ND & ND & ND & ND & \\
\hline 7 & S & ND & ND & ND & ND & ND & ND & ND & ND & ND & Drowning not \\
\hline & L & 26.85 & 21.23 & 25.68 & ND & ND & ND & ND & ND & ND & \\
\hline & W & 25.13 & 27.4 & 32.38 & ND & ND & ND & ND & ND & ND & \\
\hline & B & 22.64 & 23.31 & 24.25 & ND & ND & ND & ND & ND & ND & \\
\hline & $\mathrm{K}$ & 21.96 & 19.41 & 23.17 & ND & ND & ND & ND & ND & ND & \\
\hline & $S$ & 25.66 & 20.71 & 27.27 & ND & ND & ND & ND & ND & ND & \\
\hline 8 & L & 21.89 & 16.61 & 22.48 & ND & ND & ND & ND & ND & ND & Fresnwater \\
\hline & St & 22.20 & 21.13 & 22.81 & ND & ND & ND & ND & ND & ND & \\
\hline & W & 25.86 & 23.23 & ND & ND & ND & ND & ND & ND & ND & \\
\hline & WB & 19.13 & 14.47 & 19.61 & ND & ND & ND & ND & ND & ND & \\
\hline & $B$ & ND & ND & ND & ND & ND & ND & ND & ND & ND & \\
\hline & $\mathrm{K}$ & 34.40 & ND & ND & ND & ND & ND & ND & ND & ND & \\
\hline 9 & $S$ & 34.27 & ND & ND & ND & ND & ND & ND & ND & ND & rresnwater \\
\hline & $\mathrm{L}$ & 18.90 & 18.32 & 17.81 & ND & ND & ND & ND & ND & ND & \\
\hline & W & 31.28 & 33.65 & 33.83 & ND & ND & ND & ND & ND & ND & \\
\hline & B & 16.22 & 15.61 & 15.15 & ND & ND & ND & ND & ND & ND & \\
\hline & $\mathrm{K}$ & ND & ND & ND & ND & ND & ND & ND & ND & ND & \\
\hline 10 & S & ND & ND & ND & ND & ND & ND & ND & ND & ND & drowning \\
\hline & $\mathrm{L}$ & 22.78 & 21.52 & 22.31 & ND & ND & ND & ND & ND & ND & \\
\hline & W & 33.56 & 33.10 & ND & ND & ND & ND & ND & ND & ND & \\
\hline & $B$ & 21.76 & 22.28 & 22.72 & ND & ND & ND & ND & ND & ND & \\
\hline & $\mathrm{K}$ & 19.31 & 19.88 & 19.74 & ND & ND & ND & ND & ND & ND & \\
\hline 11 & $\mathrm{Li}$ & 26.13 & 28.67 & 27.00 & ND & ND & ND & ND & ND & ND & Freshwater \\
\hline 11 & $S$ & 21.51 & 20.84 & 21.97 & ND & ND & ND & ND & ND & ND & drowning \\
\hline & L & 16.55 & 16.52 & 17.05 & ND & ND & ND & ND & ND & ND & \\
\hline & W (1:10) & 24.22 & 24.84 & 24.93 & ND & ND & ND & ND & ND & ND & \\
\hline & $B$ & ND & ND & ND & ND & ND & ND & ND & ND & ND & \\
\hline & $\mathrm{K}$ & ND & ND & ND & ND & ND & ND & ND & ND & ND & \\
\hline 12 & $S$ & ND & ND & ND & ND & ND & ND & ND & ND & ND & Drowning not \\
\hline & L & 18.66 & 17.94 & 18.35 & ND & ND & ND & ND & ND & ND & \\
\hline & W $(1: 10)$ & 27.69 & 30.54 & 29.47 & ND & ND & ND & ND & ND & ND & \\
\hline & B & ND & ND & ND & ND & ND & ND & $33.87 \pm$ & ND & ND & \\
\hline & $\mathrm{K}$ & ND & ND & ND & ND & ND & 33.62 & 26.03 & ND & ND & \\
\hline 13 & $\mathrm{~s}$ & ND & ND & ND & ND & ND & 34.22 & 27.79 & ND & ND & Marine water \\
\hline & $\mathrm{Li}$ & ND & ND & ND & ND & ND & 34.09 & 24.63 & ND & ND & \\
\hline & St & $37.43 \pm$ & ND & ND & ND & 29.16 & 17.87 & 11.81 & 30.38 & ND & \\
\hline & B & ND & ND & ND & ND & ND & ND & ND & ND & ND & Inconclusive - \\
\hline & $\mathrm{K}$ & ND & ND & ND & ND & ND & ND & ND & ND & ND & Body \\
\hline 14 & $\mathrm{Li}$ & ND & ND & ND & ND & ND & ND & ND & ND & ND & embalmed; \\
\hline & $\mathrm{s}$ & ND & ND & ND & ND & ND & ND & ND & ND & ND & No water \\
\hline & $\mathrm{L}$ & ND & ND & ND & ND & ND & ND & ND & ND & ND & sample \\
\hline & $B$ & 31.06 & ND & ND & 25.24 & ND & ND & ND & ND & ND & Brackish \\
\hline & $\mathrm{K}$ & 29.32 & ND & ND & 21.98 & ND & ND & ND & ND & ND & water \\
\hline 15 & $\mathrm{~S}$ & 32.67 & ND & ND & 19.65 & ND & ND & ND & ND & ND & drowning: \\
\hline 10 & $\mathrm{Li}$ & $36.36 \pm$ & ND & ND & 27.61 & ND & ND & ND & ND & ND & sampling \\
\hline & $\mathrm{L}$ & 26.22 & 25.54 & 27.35 & 17.25 & ND & 35.65 & ND & ND & ND & delay affected \\
\hline & w & $36.35 \pm$ & ND & ND & ND & ND & ND & ND & 30.56 & ND & water results \\
\hline & B & 18.86 & 19.91 & 20.75 & ND & ND & ND & ND & ND & ND & \\
\hline 16 & $\mathrm{~K}$ & 24.52 & 22.46 & 22.48 & ND & ND & ND & ND & ND & ND & Freshwater \\
\hline 16 & $\mathrm{~s}$ & 28.37 & 25.08 & 25.05 & ND & ND & ND & ND & ND & ND & drowning \\
\hline & $\mathrm{L}$ & 20.35 & 18.46 & 20.39 & ND & ND & ND & ND & ND & ND & \\
\hline
\end{tabular}




\begin{tabular}{|c|c|c|c|c|c|c|c|c|c|c|c|}
\hline \multirow{3}{*}{ ज̃ } & \multirow{3}{*}{$\begin{array}{c}\text { Sample } \\
\text { Types }\end{array}$} & \multicolumn{9}{|c|}{ Real-Time PCR Threshold Crossing Point $\left(\mathrm{C}_{\mathrm{T}}\right)$ Values } & \multirow{4}{*}{$\begin{array}{c}\text { Assay } \\
\text { Conclusions }\end{array}$} \\
\hline & & \multicolumn{3}{|c|}{ Aeromonas } & \multicolumn{3}{|c|}{ Vibrio } & \multicolumn{3}{|c|}{ Photobacterium } & \\
\hline & & aerA & gyrB & chiA & fischeri & parahaemolyticus & harveyi & damselae & leiognathi & phosphoreum & \\
\hline & St & 19.88 & 17.37 & 17.96 & ND & ND & ND & ND & ND & ND & \\
\hline \multirow{5}{*}{17} & B & ND & ND & ND & ND & ND & ND & ND & ND & ND & \multirow{5}{*}{$\begin{array}{c}\text { Inconclusive } \\
\text { No water } \\
\text { sample }\end{array}$} \\
\hline & K & ND & ND & ND & ND & ND & ND & ND & ND & ND & \\
\hline & S & ND & ND & ND & ND & ND & ND & ND & ND & ND & \\
\hline & L & ND & ND & ND & ND & ND & ND & ND & ND & ND & \\
\hline & St & ND & ND & ND & ND & ND & ND & ND & ND & ND & \\
\hline \multirow{8}{*}{18} & $B$ & ND & ND & ND & ND & ND & ND & ND & ND & ND & \multirow{8}{*}{ Inconclusive } \\
\hline & K & ND & ND & ND & ND & ND & ND & ND & ND & ND & \\
\hline & $S$ & ND & ND & ND & ND & ND & ND & ND & ND & ND & \\
\hline & $\mathrm{Li}$ & ND & ND & ND & ND & ND & ND & ND & ND & ND & \\
\hline & $\mathrm{L}$ & ND & ND & ND & ND & ND & ND & ND & ND & ND & \\
\hline & St & Inhib & Inhib & Inhib & Inhib & Inhib & Inhib & Inhib & Inhib & Inhib & \\
\hline & W (Cold) & 28.52 & ND & ND & ND & ND & ND & ND & ND & ND & \\
\hline & W (Hot) & ND & ND & ND & ND & ND & ND & ND & ND & ND & \\
\hline \multirow{4}{*}{19} & B & ND & ND & ND & ND & ND & ND & ND & ND & ND & \multirow{4}{*}{$\begin{array}{l}\text { Drowning not } \\
\text { supported, no } \\
\text { water sample }\end{array}$} \\
\hline & K & ND & ND & ND & ND & ND & ND & ND & ND & ND & \\
\hline & $S$ & ND & ND & ND & ND & ND & ND & ND & ND & ND & \\
\hline & $\mathrm{L}$ & ND & 17.11 & ND & ND & ND & ND & ND & ND & ND & \\
\hline \multirow{5}{*}{20} & B & ND & ND & ND & ND & ND & ND & ND & ND & ND & \multirow{5}{*}{$\begin{array}{l}\text { Drowning not } \\
\text { supported }\end{array}$} \\
\hline & K & ND & ND & ND & ND & ND & ND & ND & ND & ND & \\
\hline & $S$ & ND & ND & ND & ND & ND & ND & ND & ND & ND & \\
\hline & $\mathrm{L}$ & ND & ND & ND & ND & ND & ND & ND & ND & ND & \\
\hline & W & 26.61 & 27.51 & ND & ND & ND & ND & ND & ND & ND & \\
\hline
\end{tabular}

